\title{
Liten kvinne
}

\section{med skarp kniv}

\author{
Ruby Mahesparan har aldri drømt om å bli verken nevrokirurg eller sjef. \\ Nå er hun begge deler.
}

Hun beklager at hun ikke har svart på e-posten tidligere, men hun har vært innlagt for å operere en brukket ankel. Til vanlig går hun aldri hjem fra jobb før nødvendig korrespondanse er à jour.

Hun åpner døren til rekkehuset på Minde i Bergen med krykkene i den ene hånden. Full avlastning av ankelen i seks hele uker.

- Jeg er en dårlig pasient, unnskylder hun. - Jeg kan ikke utstå å trenge hjelp. Nå klarer jeg meg nesten ikke alene. Ortopedene har fătt en innrømmelse - foten er den viktigste delen av kroppen. Nå sier jeg til kollegene mine at de ikke må putte foten mellom heisdørene for å stoppe den. Heller hodet, sier hun og ler godt.

- Hva skjedde?

- Det var en bagatell egentlig. Jeg kom sent hjem fra et møte og skulle løfte på en tung port. Det blåste kraftig, og jeg jo er ganske liten. Plutselig falt jeg, kroppen og porten vred seg, men foten satt fast. Jeg hørte at det knakk og tenkte at nå blir det gips. Det ble operasjon og innleggelse i stedet.

Moren har kommet fra London for å hjelpe til. Mahesparan beklager at kjøkkenet ikke er i bruk. Oppussingen er nesten ferdig, men benkeplaten var $10 \mathrm{~cm}$ for kort da den endelig kom. Hun er tydelig oppgitt. Slurv setter hun ikke pris på. Kjøkkenet er for øvrig stramt og stilig i dansk design.

Mahesparan er kjent for å være elegant, uten å spille på det. Hun er vever og beskjeden, men samtidig tydelig og uredd. Kolleger forteller om en enorm arbeidskapasitet, og at hun har evne til å se hele pasienten, ikke bare kirurgien. Vi setter oss ned i dype, myke sofaer. Spisebordet er fylt med blomster fra venner og familie etter bursdagsfeiring og beinbrudd. Jobben har sendt vin og kort. Tykke skjønnlitterære bøker ligger fremme. Hjemmet gir inntrykk av lavmælt luksus, komfort og gjestfrihet. Familien er viktig. Når kjøkkenet er planlagt, er det også tatt hensyn til at moren hennes skal kunne bruke det på mange og lange besøk i Bergen.

\section{På flukt}

Opplevelser og bakgrunn gjør kanskje noe med innstillingen til livet - ikke å ta noe for gitt. Mahesparan er født og oppvokst på Sri
Lanka. Borgerkrigen mellom tamiler og singalesere var årsak til at hun måtte flykte fra landet.

- Hvordan var det å vokse opp med krig?

- Vi lærte å leve med usikkerhet. Vi visste ikke alltid om vi kunne gå til skolen. Noen ganger måtte vi gjemme oss i bomberom i løpet av skoledagen, men det var ikke før jeg gikk på universitetet at borgerkrigen virkelig blusset opp.

Mahesparan visste tidlig hva hun ville bli. Faren var zoolog, men noen slektninger var leger, og allerede på ungdomsskolen hadde hun staket ut kursen mot medisin.

- Skolesystemet i Sri Lanka er som det britiske, og medisinstudiet er delt i preklinikk og klinikk. Jeg var nettopp ferdig med preklinisk utdanning da urolighetene tiltok. Jeg bodde

\section{«Alt jeg eide, var $\varnothing$ delagt»}

i en leilighet like ved universitetet. Ryktene gikk om at noe kom til å skje, og jeg kjørte hjem, 18 kilometer, i mørket på en scooter samme kveld til familien min. Den natten angrep de universitetet og boligene like ved. - Du unnslapp så vidt?

- Ja, det var nære på, sier hun udramatisk. - Noen uker senere var jeg tilbake i leiligheten. Alt jeg eide, var ødelagt. Studenter og akademikere var et mål. Vi skjønte at vi måtte flykte.

- Foreldrene dine bosatte seg i England, hvorfor kom du til Norge?

- Broren min hadde allerede flyttet til Norge for å studere på Norges teknisknaturvitenskapelige universitet flere år i forveien. Han foreslo at jeg skulle komme etter. I Norge er det billig å studere. I Storbritannia er det dyrt. Jeg måtte velge det som var mulig. Det eneste problemet var at jeg ikke snakket et ord norsk.

- Broren din bodde i Trondheim, hvorfor valgte du Bergen?

- Familien til mannen min bodde her allerede, vi var kjærester da. De tok seg av meg.
Jeg rakk ikke oppstart av norskkurs om høsten, for reisen fra nord til flyplassen i sør på Sri Lanka tok lengre tid enn vi trodde. Vi måtte reise med traktor, båt og vandre lange strekninger. Det var litt av en ekspedisjon. Først i oktober var jeg fremme i Norge.

- Du lærte deg norsk på kort tid?

- Da jeg først kom hit, tenkte jeg at jeg aldri kom til å lære språket. Jeg hadde bare lyst til å reise hjem igjen. Så begynte jeg på et intensivkurs. Jeg snakker flytende engelsk og lærte meg at jeg måtte tenke på engelsk og oversette til norsk. Skriftlig gikk det bra, og heldigvis var det en skriftlig prøve som skulle til for å bli tatt opp ved medisinstudiet. Muntlig tok det lengre tid.

\section{Dobbeltløp}

Hun kom inn på medisinstudiet både i Bergen og Oslo. I Oslo fikk hun godkjent preklinisk avdeling, men kjente ingen. I Bergen måtte hun starte fra begynnelsen. Hun valgte Bergen.

- Jeg kunne stoffet, men jeg gikk på forelesning for å lære meg de norske ordene. Jeg kjedet meg, så jeg gikk på avdelingene for å høre om noen hadde et forskningsprosjekt hvor jeg kunne bidra. Slik kom jeg over hjernesvulstene. Jeg har alltid likt hjernen, det er jo et komplekst og spennende organ, og det å få forske på hjernen virket ekstra spennende. Kvelder og helger brukte jeg til å forske, mens andre medstudenter leste. Veilederen min skjønte at jeg måtte repetere det jeg allerede hadde lært, og hjalp meg med å søke på nytt om å få godkjent den prekliniske utdanningen. Nå fikk jeg innvilget søknaden, og jeg rykket opp fra PK 92 til PK 91. Plutselig var jeg i klinisk utdanning. Jeg sparte i hvert fall et års studietid.

Effektivitet er et kjennetegn, og hun har spart tid på mange måter.

- Jeg har alltid likt å gjøre flere ting på en gang, slår hun fast.

Mahesparan forsket og studerte samtidig. Da hun fikk midlertidig lisens, begynte hun å jobbe ved kirurgisk avdeling.

- Jeg ble tatt godt imot og merket fort at jeg likte å operere. Jeg ble ofte tidlig ferdig med det jeg skulle på avdelingen, og gikk på operasjonsstuen. Hos hjertekirurgene ved 


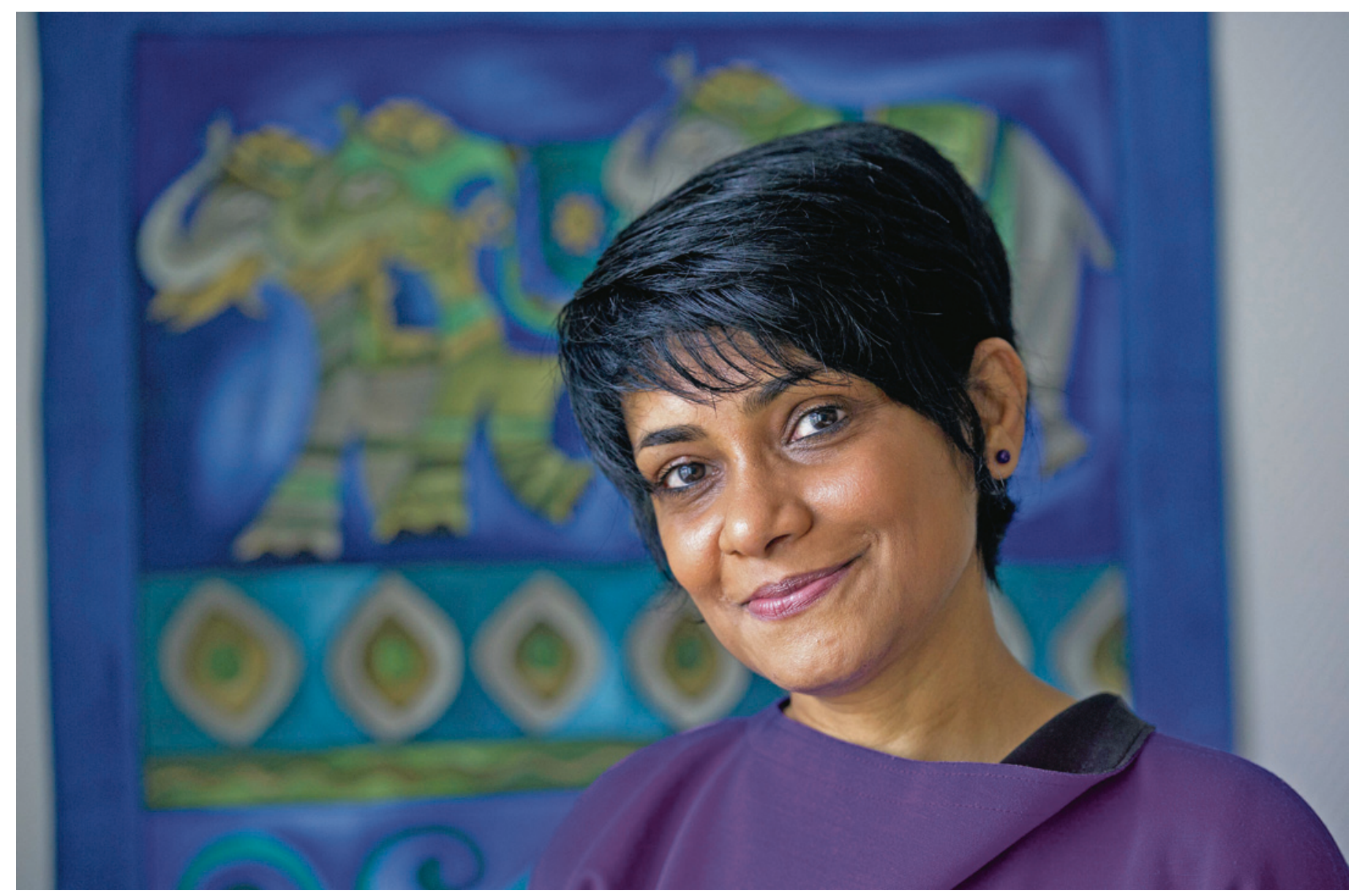

\section{Ruby Mahesparan}

- Cand.med. Universitetet i Bergen 1997

- Spesialist i nevrokirurgi 2006

- Dr.med. Universitetet i Bergen 2000

- Avdelingssjef ved Klinikk for nevrokirurgi, Haukeland universitetssykehus 2011-

- Leder av Norsk nevrokirurgisk forening 2013-
Haukeland universitetssykehus fikk jeg stå midt i feltet. Jeg er så liten at jeg ikke sto i veien, og jeg har små hender, angivelig perfekt for å holde hjertet. Kirurgene sendte meg hjem med en bok om suturer og beskjed om å øve på en pute. Etter hvert fikk jeg frilegge vener. Jeg trivdes godt med kirurgien, men måtte ta turnus og giøre ferdig graden før jeg kunne starte for fullt et sted. Så ble jeg overtalt av biveilederen min, som er nevrokirurg, til å prøve nevrokirurgi.

\section{Vant til å jobbe mye}

- Etter fem år var jeg ferdig spesialist. Jeg tror jeg hadde dobbelt så mange inngrep som jeg trengte.

- Hvor henter du energien fra?

- Jeg elsker jobben min og får overskudd av å behandle pasienter. Jeg er sosial og liker å gå ut. Jeg har reist en god del og har ikke savnet noe.

- Hvorfor ble du avdelingssjef?

- Jeg hadde aldri drømt om det selv. Det er noen andre som har sett at jeg hadde talent, og jeg ble oppfordret til å søke. Jeg er nok blitt det fordi jeg er systematisk og ansvarsfull.

- Har det vært vanskelig å være kvinne i et mannsdominert fag?
- Da jeg begynte, visste jeg ikke at det var så få kvinner i nevrokirurgi. Jeg ble overrasket da jeg kom på det første kurset og så hvor mange menn det var. På kurset opplevde jeg at noen stilte spørsmål ved om det var mulig å være kvinne og nevrokirurg. Det irriterte meg, det har jeg aldri opplevd her. Hvis jeg har en funksjonshemning, så er det at jeg er liten. Jeg må jo stå på krakk! Jeg husker at vi så på bilder av en prolaps i en omfangsrik mann helt i starten av karrieren min. Radiologen mente det bare var jeg som kunne operere ham, og foreslo at jeg kunne kle meg sterilt, klatre inn og fjerne det.

Hun har sans for humoren på operasjonsstuen.

- Man må jo ikke ta ting altfor bokstavelig. Det hender at pasienter sier til meg at jeg ikke kan være mer enn 16 år. Det nytter jo ikke å bli fornærmet.

\section{Vil inspirere kvinner}

- Jeg har holdt foredrag for medisinstudentene. Jeg håper at flere skal skjønne at det å være kirurg ikke er naturlig koblet til kjønn.

- Mange tenker kanskje at det ikke er så familievennlig? 
- Hvilken legejobb er egentlig familievennlig? Det handler mest om hvordan man organiserer seg. Jeg har dessverre ikke barn selv, men jeg har jo kolleger med barn. Man må bestemme seg for hva man vil ha tid til. - Hvordan er det å være en ung avdelingssjef?

- Da jeg fikk utfordringen, vegret jeg meg litt. Jeg var yngst av overlegene og har fortsatt mye å lære. Jeg gikk med på å begynne på lederutdanning for å få litt smak av hva ledelse innebærer, den startet i oktober. I november samme år sa avdelingssjefen at han ville gi seg, og jeg overtok. Mastergraden i ledelse rakk jeg aldri å gjøre ferdig. Jeg fikk tillit fra kollegene mine, og de ønsket meg som leder. Jeg synes ikke at det er en ulempe å være en ung leder. - Blir avgjørelsene dine respektert?

- Det er det minste problemet. Jeg har jobbet med å lage retningslinjer og gode systemer for at flest mulig skal ha det bra. Samtidig må jeg ta noen ubehagelige avgjørelser. Det har vært en bratt læringskurve. Jeg synes avdelingen fungerer godt nå. Jeg er stolt av at vi har en god struktur for utdanning, og spesialiseringen ser jeg på som et lederansvar.

- Hva er det du ikke får gjort når du er sjef?

- Jeg får ikke lært opp nye leger på operasjonsstuen. Det er noe jeg savner. Jeg har lyst til å gjøre nye leger trygge, for jeg har hatt gode lærere selv.

\section{Etiopia}

Nevrokirurgisk avdeling i Bergen har et samarbeid med Etiopia om utveksling og opplæring av nevrokirurger.

- Det er noe av det flotteste jeg har fått lov til å gjøre som nevrokirurg. Jeg er så glad jeg fikk reise til Etiopia. Jeg blir nesten rørt til tårer når jeg tenker på det.

- Hvorfor valgte du å reise ut?

- Først tenkte jeg at dette var feil fagområde å satse på $\mathrm{i}$ et så fattig land. Det krever for mye ressurser. Så reiste jeg ned og så behovet. Barn med vannhoder og mødre som hadde gått $\mathrm{i}$ fire dager for å ta dem med til oss.

- Hva var vanskeligst?

- Du må klare deg med et minimum av utstyr. Der må jeg bruke håndbor og sag, utstyr som ikke er en del av opplæringen i Norge.

- Hvordan taklet du sitasjonen?

- Jeg visste at jeg ikke skulle prøve på noe heroisk. Vi gjør inngrep som er viktige for funksjon. Jeg har operert unge pasienter med meningiomer som holder på å miste synet. Noen av kollegene mine var redd jeg ikke skulle få den nødvendige respekten der som kvinne. Under den første operasjonen hadde jeg mange tilskuere. Det gikk heldigvis fint, de så at jeg kunne operere, og siden har jeg aldri hatt problemer med å bli respektert.

- Hva får du igjen for det?

- Det er et takknemlig arbeid, og jeg klarer nesten ikke å reise derfra. Forrige gang skulle jeg foreta to operasjoner også aller siste dag. Så ville ikke hotellet godta visakortet. Det var så vidt jeg kom meg av gårde.

Hun kaster ikke bort tiden når hun er der.

- I Etiopia jobber jeg lange dager hver

dag. Likevel kommer jeg hjem full av energi.

- Hvor er du om ti år?

- Jeg er fortsatt nevrokirurg, jeg liker faget mitt og vet at jeg er en god kirurg.

\section{«Hvilken legejobb er egentlig familievennlig?»}

Jeg tror ikke at jeg kommer til å bli en ren administrator, selv om det er mer lystbetont enn det var i starten.

Hun er åpen for at nye muligheter kan åpne seg.

- Jeg har jo opplevd tilfeldigheter som har vært med på å bestemme retningen av karrieren min, og i tillegg jeg skal ikke legge skjul på at jeg liker utfordringer. - Hvordan er det å være lege og leder?

- Det er krevende. Jeg kan føle meg ganske alene. I felles lederforum er det impulser å hente, men vi har forskjellige utfordringer. Jeg har ønsket meg mer støtte fra Legeforeningen i den posisjonen jeg er i nå. Jeg har forresten fått en mentor som er lege. Vi rakk å møtes en gang før jeg brakk beinet.

- Hvordan trives du med å være leder?

- Jeg trives godt med det, selv om ikke alt er like spennende. Jeg setter ikke pris på lange, uproduktive møter, men jeg får samtidig mulighet til å utvikle faget, avdelingen og skape et bedre miljø.

- Har du alltid tatt ansvar?

- Jeg har alltid vært beskjeden, men likevel tatt lederansvar. Da jeg var barn, ledet jeg skolekorpset, studentforumet og idrettslaget. Faren min sendte meg av gårde til indisk dans, han mente jeg måtte bli mer vant til å vise meg frem. Jeg tok diplom $i$ indisk dans da jeg var 12 år. Da måtte vi danse i tre timer foran et stort publikum. Jeg tror ikke beskjedenheten står i veien for meg nå.

\section{Balansegang}

- Hvordan er det å være leder for kolleger?

- I begynnelsen var det litt rart å ha en annen rolle overfor kolleger, men jeg er veldig bevisst min rolle som leder, og hva den innebærer. Jeg tror at jeg har klart å balan- sere det å være kollega og leder selv om det tidvis er utfordrende. Jeg har flinke og samarbeidsvillige kolleger og føler at jeg får både respekt og tillit fra dem.

Jeg tror at det hjelper meg mye at jeg også jobber klinisk med fulle vakter. Dessuten er jeg til stede og får med meg en god del av det som skjer på avdelingen. Jeg tror jeg passer best til å lede en liten avdeling, for jeg er avhengig av å ha oversikt.

- Hva kan være vanskelig med det?

- Det blir mye jobbing. Jeg delegerer en del, men først når jeg er helt sikker på at oppgaven blir gjort. Jeg vil så gjerne gjøre en god jobb.

Hun er tydelig på hvor lojaliteten ligger.

- Det er viktig å tenke på pasientene og de ansatte. Jeg kan ikke gjennomføre endringer jeg vet er umulige i den praktiske virkeligheten.

Mahesparan synes det er mer utfordrende å være lege-leder enn kvinnelig leder, men hun har gjort seg noen erfaringer hun har tatt til seg.

- Jeg har møtt noen ledere som behandler kollegene dårlig. Jeg har sagt på avdelingen at de må dunke meg i hodet hvis jeg blir en slik leder, spøker hun.

- Mannen din er bioingeniør på samme sykehus. Du går ikke hjem før du er ferdig med jobben, hvordan er det å bo sammen med deg?

- Han er vant til at jeg jobber mye. Dessuten vet han at det er best for oss begge to at jeg er ferdig med dagens dont når jeg kommer hjem. Jeg blir i dårlig humør hvis jeg har arbeid liggende. Han har dessuten sine egne rutiner, tidligere aktiv cricketspiller som han er, så vi er fornøyde begge to. - Hva liker du å gjøre når du ikke jobber?

- Jeg er veldig glad i å være sammen med familien, både min egen og svigerfamilien. Ellers liker jeg å kjøpe pene ting. Det er noe alle vet, smiler hun.

Andre arbeidsgivere har forsøkt å rekruttere henne, men hun har ikke bitt på kroken.

- Jeg har det bra her i Bergen. Avdelingen har gitt meg så mye, og jeg synes jeg bør gi litt tilbake.

På slutten av samtalen dukker moren opp med en deilig lunsj, salat med litt smak av chili, mens Mahesparan presiserer at leger som er ledere, trenger støtte. Kunne ikke fagforeningen se på det?

- Hva med at du tar et initiativ? Hvis du ser at noe mangler?

- Jo.

Hun er typen til å ta ansvar.

- Jeg kunne kanskje det.

\section{Marit Tveito}

marit.tveito@me.com

Alderspsykiatrisk avdeling

Diakonhjemmet Sykehus 